\title{
Determination of Galendo's Shelf Life on Various of Storage Temperatures by Arrhenius Method
}

\author{
Asep Dedy Sutrisno ${ }^{1}$, Wisnu Cahyadi ${ }^{2}$ \\ 1,2Pasundan University, Bandung, Indonesia \\ Email: sister.asepdedysutrisno@unpas.ac.id
}

\begin{abstract}
This study aims to estimate the shelf life by applying the Arrhenius formula model to "galendo" which is vacuum packed and stored at various temperatures. Estimation of the shelf-life limit of galendos was carried out by measuring the peroxide number and sensory values of galendos which were deliberately kept open without being packed at room temperature $\left(25^{\circ} \mathrm{C}\right)$. The sensory values used as the threshold for consumer rejection of the level of galendo's rancid odor were achieved on the 27th day of storage and the current peroxide count value was $42.2724 \mathrm{meg} / \mathrm{kg}$. Galendo which was vacuum packed with aluminum foil and stored at various temperatures of $15^{\circ} \mathrm{C}, 25^{\circ} \mathrm{C}$, and $35^{\circ} \mathrm{C}$, then the shelf life was determined using the Arrhenius and Q10 models based on the parameters of the total peroxide number (TPN) and the total microbial content. Based on the experiment in this study, the estimation results of galendo's shelf life based on the total peroxide number (TPN) test parameter show that storage at $15^{\circ} \mathrm{C}$ has a shelf life of 83 days with a deterioration rate $(\mathrm{k})$ of 0.0207 , storage at $25^{\circ} \mathrm{C}$ shelf life 67 days with a deterioration rate $(k) 0.0247$, and storage at a temperature of $35{ }^{\circ} \mathrm{C}$ for 58 days with a deterioration rate $(\mathrm{k}) 0.0286$. The rate of quality degradation with a value of $\mathrm{Q}_{10}\left(15^{\circ} \mathrm{C}\right.$ $\left.25{ }^{\circ} \mathrm{C}\right)$ of 1.23 and a value of $\mathrm{Q}_{10}\left(25^{\circ} \mathrm{C}-35^{\circ} \mathrm{C}\right)$ of 1.16 . The higher the storage temperature, the higher the microorganism content.
\end{abstract}

Keywords: Galendo, Packaging, Storage, Arrhenius, Shelf Life.

\section{A. INTRODUCTION}

Coconut plantation centers in West Java, Indonesia, such as Ciamis Regency, many small industry players process coconut into coconut oil or better known as "kelentik" cooking oil. The production process of kelentik cooking oil is produced by a by-product, namely oil residue or better known as "galendo" (Special food from the by-product of coconut cooking oil processing). Initially galendo was known as one of the traditional foods for rice friends. Currently, galendo which is mostly produced in Ciamis Regency has developed into a traditional food product that is processed on a small industrial scale.

Galendo is now also available in various forms of products that are printed in various forms such as biscuits and chocolate bars and combined with various toppings (cheese, chocolate, or banana) and various flavors (milk, peanut, sesame or chocolate). In addition, Galendo, which was originally packaged only using traditional woven bamboo packaging, now looks good with various forms of packaging ranging from plastic and aluminum foil combined with paper or cardboard. 
Although it has been known for a long time, Galendo's marketing is still very limited, which is only marketed at the provincial level. The market reach is limited because galendo which is rich in protein and fat is very perishable and has a relatively short shelf life.

Efforts to maintain the quality of galendo's by selecting the right materials and packaging techniques which are followed up by determining the shelf life of these products will be valuable information for small coconut processing industry entrepreneurs to improve the quality of handling and storage techniques of galendos properly and precisely, so that they can expand market reach.

Seeing the above facts, it is necessary to dig up scientific information that provides an overview of the right type of packaging material to package galendo, from the various types of packaging materials that are now used to package galendo, namely woven bamboo (traditional packaging), plastic, paper or aluminum foil that are capable of provides the best protection against packed galendo.

Other important information is about packaging techniques that are able to maintain the durability of the packed galendo. There are two types of sealing methods, namely closing with a sealer without vacuum and closing with a vacuum system. In accordance with the nature of galendos, it is necessary to observe the most optimal sealing technique in maintaining its durability.

In addition, temperature is also a factor that affects changes in food quality. The higher the storage temperature, the faster the reaction rate for various chemical compounds contained in foodstuffs. Food storage, at room temperature, should remain constant from time to time. If the storage temperature remains or does not change, the problem formulation will be simpler, namely to estimate the rate of deterioration, simply by using the Arrhenius equation, $\mathrm{k}=\mathrm{k}_{\mathrm{o}} \mathrm{e}^{-\mathrm{E} / \mathrm{RT}}$.

Galendo is a food that contains the main ingredient in the form of oil or fat. In accordance with the Arrhenius model, fat/oil oxidation reactions include chemical reactions that have low activation energy (2-15 calories $/ \mathrm{mol})$ and one reaction order (Arpah, 2001).

This research has been conducted with the aim of determining the shelf life of galendos that are packaged and stored at various temperature conditions.

\section{B. MATERIALS AND METHODS}

\section{Materials}

The raw material used to make good galendo is old coconut 30 days after it is made from manggar (flowers). The materials used for chemical analysis are acetic acid: chloroform (2:1), saturated KI solution, standard $\mathrm{Na}_{2} \mathrm{~S}_{2} \mathrm{O}_{3}$ solution, $1 \%$ starch solution, distilled water. Meanwhile, the materials used for the microbiological test were sterile water and plate count agar (PCA). 


\section{Methods}

The research that has been carried out in determining the shelf life of galendo, consists of two stages, namely the first and second research stages. The first stage of research was carried out on:

a. Chemical analysis of galendo's ingredients, namely water content, ash content, fat content, carbohydrates and protein, peroxide number, free fatty acid content and total microbes.

b. Organoleptic test to determine the level of consumer preference for the stored galendo condition using the hedonic test using scaling or scoring.

c. Analyze the Peroxide Numbers every day until the value of the peroxide number is obtained when the panelists' rejection of the taste and aroma of galendo occurs due to a clear detection of rancidity (sensory value score $=2$ ). The value of the Peroxide Number reached at the limit of rejection by the panelists will be used as a reference for the value of the peroxide number to be achieved by Galendo which will be observed at the next research stage, as an indicator that Galendo has reached its shelf life limit.

The second stage of research was carried out on determining the shelf life of galendo which is packaged with aluminum foil packaging and the best packaging technique is in vacuum conditions, and stored at various storage temperatures, namely: $15{ }^{\circ} \mathrm{C}, 25^{\circ} \mathrm{C}$ and $35{ }^{\circ} \mathrm{C}$. The response of the observations was made to the total peroxide number (TPN) and the content of microorganisms.

The treatment design in the second stage of research was carried out to determine the deterioration in the quality of galendos stored for 30 days at various storage temperatures, namely temperatures of $15{ }^{\circ} \mathrm{C}, 25^{\circ} \mathrm{C}, 35^{\circ} \mathrm{C}$. The response of the observations was made to the number of peroxide numbers.

To determine the estimation of galendo's shelf life through a decrease in quality parameters (peroxide number values) at various temperature levels, calculations are carried out using the Arrhenius method.

The calculation method in estimating galendo's shelf life is to use the Arrhenius equation which shows the dependence of the deterioration reaction rate on temperature with the following formula:

$$
\begin{aligned}
& \mathrm{k}=\mathrm{k}_{\circ} \mathrm{e}^{-\mathrm{E} a / R T} \\
& \ln \mathrm{k}=\ln \mathrm{k}_{\mathrm{o}}-(\mathrm{Ea} / \mathrm{RT}) \\
& \ln \mathrm{k}=\ln \mathrm{k}_{\mathrm{o}}-\{(\mathrm{Ea} / \mathrm{R}) \times(1 / \mathrm{T})\}
\end{aligned}
$$

Where:

$\mathrm{ko}=$ pre-exponential constant or absolute rate constant

$\mathrm{k}=$ constant rate of reaction at temperature $\mathrm{T}$

$\mathrm{Ea}=$ Activation energy $(\mathrm{J} / \mathrm{mol})$

$\mathrm{R}=$ ideal gas constant $\left(8,314 \mathrm{JK}^{-1} \mathrm{~mol}^{-1}\right)$

Further calculations are used the $\mathrm{Q}_{10}$ model, where this model is used to estimate how much change in the reaction rate or deterioration rate of food products stored at various temperatures $\left(\Delta t=10^{\circ} \mathrm{C}\right)$. Model $\mathrm{Q}_{10}$ can be formulated as follows: 


$$
\begin{aligned}
\mathrm{Q}_{10} & =\frac{\text { The rate of deterioration at temperature } \mathrm{T}+10}{\text { The rate of deterioration at temperature }} \\
& =\operatorname{tn}(\mathrm{T}+10) / \mathrm{tn}_{\mathrm{n}}(\mathrm{T})
\end{aligned}
$$

Where:

$$
\begin{aligned}
& \mathrm{T} \quad=\text { storage temperature in }{ }^{\circ} \mathrm{C} \\
& \operatorname{tn}(\mathrm{T}) \quad=\text { shelf life if stored at temperature } \mathrm{T} \\
& \mathrm{tn}(\mathrm{T}+10)=\text { shelf life if stored at a temperature of } \mathrm{T}+10
\end{aligned}
$$

By using a linear regression technique, the regression equation will be obtained for each temperature of $15^{\circ} \mathrm{C}, 25^{\circ} \mathrm{C}$ and $35^{\circ} \mathrm{C}$, namely $\mathrm{y}=\mathrm{a}+\mathrm{bx}$

Furthermore, if the value of the rate of deterioration (peroxide number/day) is applied in the Arrhenius formula, the equation for deterioration at each temperature level is:

$$
\begin{aligned}
& \mathrm{k} \quad=\mathrm{k}_{\mathrm{o}} \quad \mathrm{e}^{-\mathrm{E} a / \mathrm{RT}} \\
& \ln \mathrm{k}=\ln \mathrm{k}_{\mathrm{o}}-\{(\mathrm{Ea} / \mathrm{R}) \times(1 / \mathrm{T})\}
\end{aligned}
$$

because $\ln \mathrm{k}_{\mathrm{o}}$ and $\mathrm{Ea} / \mathrm{R}$ are constant numbers, the equation can be written as:

$\ln \mathrm{k}=\mathrm{A}-\mathrm{B}(1 / \mathrm{T})$

so that if each value of $\ln \mathrm{k}$ and $1 / \mathrm{T}$ is plotted on a graph, it will be obtained as shown in Figure 1.

Finally the estimated shelf life is calculated from:

Total deterioration of quality until the end of shelf life

Deterioration of quality per day

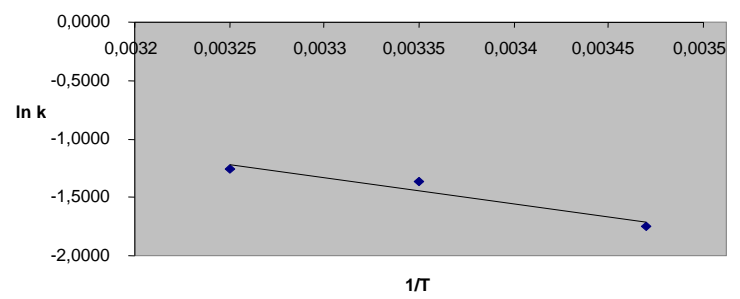

Figure 1. Graph of the Relationship between $\ln \mathrm{k}$ and 1/T

The response designs observed in this study included:

a. Organoleptic Test

b. Chemical response, namely to the number of peroxides

c. Microbiological Response, Observations of microbial growth in Galendo were carried out by calculating microbes using the Total Plate Count (TPC) method.

Observation of the value of the peroxide number was carried out for galendos stored at a predetermined storage temperature, namely on days 1, 6, 12, 18, 24 and 30. Observations were also made on the total microbes only at the beginning and end of storage. 


\section{RESULT AND DISCUSSION}

\section{First Stage Research}

Chemical analysis of the composition of galendo ingredients taken from galendo producers in Ciamis Regency, including moisture content, ash content, protein, fat and carbohydrate content, free fatty acid (FFA) content, peroxide value and microbial content (total microbes ). The results of the analysis are as follows: Water content $11.1685 \%$, ash $3.8126 \%$, fat $8.5166 \%$, protein $37.8174 \%$, carbohydrates $38.6850 \%$, free fatty acids (FFA) $3.1065 \mathrm{mg} / \mathrm{g} \mathrm{KOH}$, peroxide number $1.5652 \mathrm{meq} / \mathrm{kg}$, number of microbes 115 colonies/g.

The organoleptic test results for determining the limit of panelists rejection of the taste and aroma of galendo due to clear detection of rancidity (sensory value score $=2$ ), the peroxide number value was $42.2724 \mathrm{meq} / \mathrm{kg}$ (used as a reference for expiration).

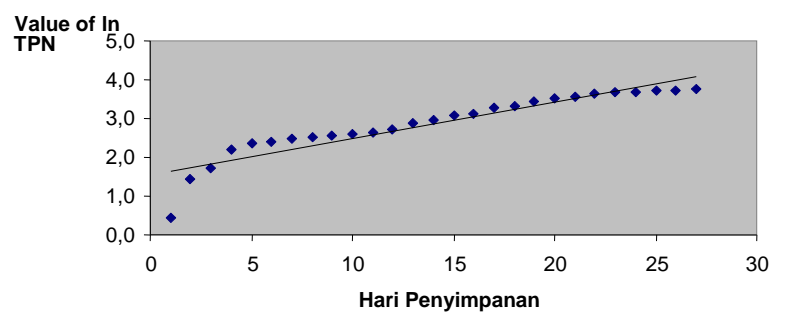

Figure 2. Graph of unpackaged galendo rancidity trend

\section{Second Stage Research}

The results of observations on the increase in the peroxide number of galendo packed with vacuum aluminum foil and stored at $15^{\circ} \mathrm{C}, 25^{\circ} \mathrm{C}$ and $35^{\circ} \mathrm{C}$ is like Table 1 .

Table 1. Measurement Results of the Total Peroxide Number (meq/kg).

\begin{tabular}{|c|c|c|c|}
\hline Storage Temperature & Storage (day) & $\begin{array}{c}\text { Average Peroxide } \\
\text { Numbers (meq/kg) }\end{array}$ & Value of ln TPN \\
\hline & 1 & 5.4917 & 1.7032 \\
& 6 & 10.9450 & 2.3928 \\
& 12 & 11.1706 & 2.4132 \\
& 18 & 11.7419 & 2.4631 \\
& 24 & 11.8502 & 2.4723 \\
& 30 & 12.1288 & 2.4955 \\
\hline \multirow{3}{*}{$25^{\circ} \mathrm{C}$} & 1 & 5.4927 & 1.7032 \\
& 6 & 12.2738 & 2.5075 \\
& 12 & 13.3761 & 2.5935 \\
& 18 & 13.8705 & 2.6298 \\
& 24 & 14.0810 & 2.6448 \\
& 30 & 15.0452 & 2.7111 \\
\hline \multirow{3}{*}{${ }^{\circ} \mathrm{C}$} & 1 & 5.4917 & 1.7032 \\
& 6 & 12.4951 & 2.5253 \\
& 12 & 13.8237 & 2.6263 \\
& 18 & 14.2718 & 2.6582 \\
& 24 & 14.8285 & 2.6966 \\
& 30 & 15.8151 & 2.7610 \\
\hline
\end{tabular}


From the tabulation above, if it is plotted in a graph, a description of the relationship between value of $\ln$ total peroxide number (TPN) and the storage time of galendo is shown in Figures 3, 4 and 5.

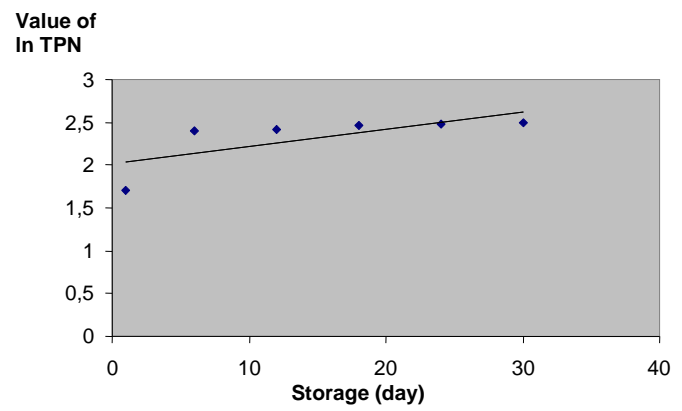

Figure 3. Graph of storage time relationship with In TPN of galendo in Vacuum packaging with aluminum foil at $15^{\circ} \mathrm{C}$.

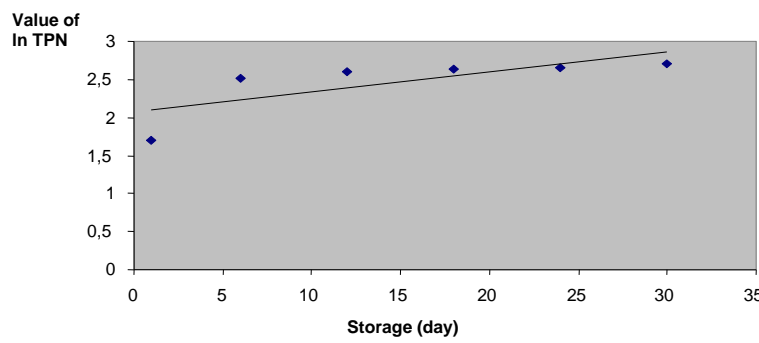

Figure 4. Graph of storage time relationship with In TPN of galendo in Vacuum packaging with aluminum foil at $25^{\circ} \mathrm{C}$.

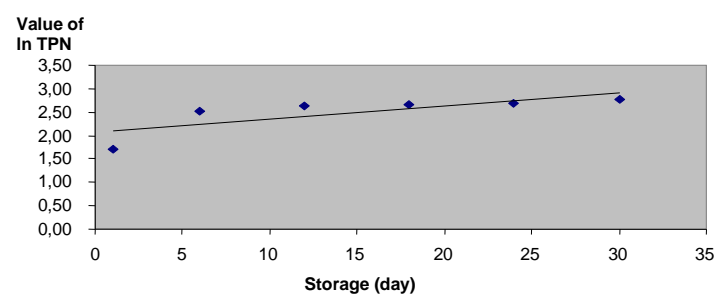

Figure 5. Graph of storage time relationship with In TPN of galendo in Vacuum packaging with aluminum foil at $35^{\circ} \mathrm{C}$.

From the three graphs, it can be calculated the rate of reaction of peroxide formation ( $\mathrm{k}$ value) of galendo in Vacuum packaging with aluminum foil from each treatment as listed in Table 2. 
Table 2. Results of Calculation of Linear Regression Relationship between ln TPN (meq/kg) and storage (day).

\begin{tabular}{|c|c|c|}
\hline Storage Temperature & Line Equations & k (meq/day) \\
\hline $15^{\circ} \mathrm{C}$ & $\begin{array}{l}Y=2.0172+0.0202 X \\
R^{2}=0.5223\end{array}$ & 0.0202 \\
\hline $25^{\circ} \mathrm{C}$ & $\begin{array}{l}Y=2.0686+0.0261 X \\
R^{2}=0.5709\end{array}$ & 0.0261 \\
\hline $35^{\circ} \mathrm{C}$ & $\begin{array}{l}Y=2.0732+0.0278 X \\
R^{2}=0.5936\end{array}$ & 0.0278 \\
\hline
\end{tabular}

From table 2 above, the $\mathrm{k}$ values are applied to the Arrhenius formula, namely: $\mathrm{K}=\mathrm{k}_{\mathrm{o}} \cdot \mathrm{e}^{-\mathrm{E} / \mathrm{RT}}$ atau $\ln \mathrm{k}=\ln \mathrm{k}_{\mathrm{o}}-\mathrm{E} / \mathrm{RT}$

because $\ln \mathrm{k}_{\mathrm{o}}$ and $-\mathrm{E} / \mathrm{R}$ are constant numbers, then the equation can be written:

$\ln \mathrm{k}=\mathrm{A}+\mathrm{B} 1 / \mathrm{T}$

If each value of $\mathrm{k}$ and $1 / \mathrm{T}$ listed in Table 3 is plotted on a graph, the graph will be obtained as shown in Figure 6, with the equation:

$\ln \mathrm{k}=1.2372-1473.9(1 / \mathrm{T})$.

Table 3.Temperature calculation data and $\mathrm{k}$ value

\begin{tabular}{|c|c|c|c|c|}
\hline $\mathbf{T}\left(\mathbf{}{ }^{\mathbf{K}}\right)$ & $\mathbf{1} / \mathbf{T}$ & $\mathbf{k}$ & $\mathbf{l n} \mathbf{k}$ & $\mathbf{R}^{\mathbf{2}}$ \\
\hline 288 & 0,00347 & 0,0202 & $-3,9020$ & 0,5223 \\
298 & 0,00335 & 0,0261 & $-3,6458$ & 0,5709 \\
308 & 0,00325 & 0,0278 & $-3,5827$ & 0,5936 \\
\hline
\end{tabular}

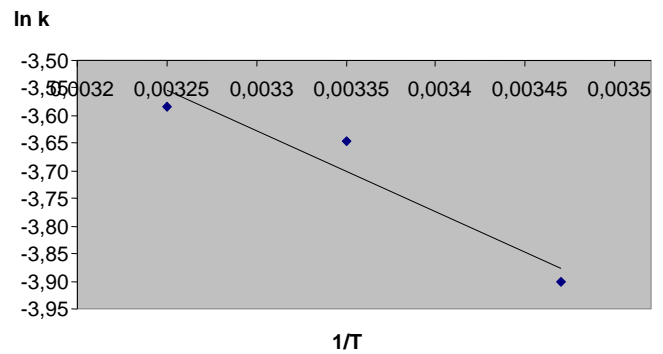

Figure 6. The Graph of the Relationship between the Value of $\ln k$ and 1/T

Thus, the value of $\mathrm{E}$ can be obtained from the graph, namely:

$-\mathrm{E} / \mathrm{R}=\mathrm{B}$

$-\mathrm{E} / \mathrm{R}=-1473.9$

Where:

$\mathrm{R}=1.986 \mathrm{cal} / \mathrm{mol}{ }^{\circ} \mathrm{K}$

$\mathrm{E}=2927.16 \mathrm{cal} / \mathrm{mol} \approx 2.927 \mathrm{kcal} / \mathrm{mol}$

while the value of $\mathrm{k}_{\mathrm{o}}$ can be obtained from the graph as follows:

$\ln \mathrm{k}_{\mathrm{o}}=\mathrm{A}, \ln \mathrm{k}_{\mathrm{o}}=1.2372, \mathrm{k}_{\mathrm{o}}=3.45$

Thus the kinetics model or equation for the rate of degradation of the galendo is:

$\mathrm{k}=\mathrm{k}_{\mathrm{o}} \cdot \mathrm{e}^{-\mathrm{E} / \mathrm{RT}}, \quad \mathrm{k}=3.45 \cdot \mathrm{e}^{-1473.9(1 / \mathrm{T})}$

So that the rate of degradation of galendo's quality at the three temperature levels can be calculated by the Arrhenius equation, as follows:

Temperature $15^{\circ} \mathrm{C}$ 
$\mathrm{k}=\mathrm{k}_{\mathrm{o}} \cdot \mathrm{e}^{-\mathrm{E} / \mathrm{RT}}, \mathrm{k}=3.45 \cdot \mathrm{e}^{-1473.9(1 / 288)}$

$\mathrm{k}=0.0207 \mathrm{meq} / \mathrm{day}$

Temperature $25^{\circ} \mathrm{C}$

$\mathrm{k}=3.45 \cdot \mathrm{e}^{-1473.9(1 / 298)}, \mathrm{k}=0.0247 \mathrm{meq} / \mathrm{day}$

Temperature $35^{\circ} \mathrm{C}$

$\mathrm{k}=3.45 . \mathrm{e}^{-1473.9(1 / 308)}, \mathrm{k}=0.0286 \mathrm{meq} /$ day

Furthermore, it can be calculated the shelf life of galendos stored at various temperature levels, based on the first order reaction kinetics with the following formula:

$d C z / d t=k C z \rightarrow(d t / C z) d C z / d t-k C z(d t / C z)$

$\int d C z=k \int d t \rightarrow \ln C z=k t$

If $\mathrm{C}^{\circ} \mathrm{Z}$ is the peroxide concentration at time $\mathrm{t}=0$ (initial storage) and $\mathrm{Cz}$ is the peroxide concentration at time $\mathrm{t}$, then:

$\ln C^{o} z / C z=k t, \ln C^{o} z-\ln C z=k t$

$t=\left(\ln C^{o} z-\ln C z\right) / k$

If from the results of the first stage research, data shows that the level of rancidity which is the limit of consumer rejection is reached at the total value of the galendo's peroxide number is $42.2724 \mathrm{meq} / \mathrm{kg}$, then the estimated shelf life of galendo's stored at various temperature levels can be calculated as follows:

Shelf life $(\mathrm{tn})=\underline{\operatorname{Ln}(42,2724)-\ln \text { (peroxide concentration at initial storage) }}$

constant $(\mathrm{k})$

so that:

$$
\begin{aligned}
& \operatorname{tn}\left(15^{\circ} \mathrm{C}\right)=\frac{3.7441 \mathrm{meq} / \mathrm{kg}-2.0172 \mathrm{meq} / \mathrm{kg}}{0,0207 \mathrm{meq} / \mathrm{kg} / \mathrm{day}} \\
& =83.42 \text { days } \approx 83 \mathrm{days} \\
& \operatorname{tn}\left(25^{\circ} \mathrm{C}\right)=\frac{3.7441 \mathrm{meq} / \mathrm{kg}-2.0686 \mathrm{meq} / \mathrm{kg}}{0,0247 \mathrm{meq} / \mathrm{kg} / \mathrm{day}} \\
& =67.83 \text { days } \approx 67 \mathrm{days} \\
& \operatorname{tn}\left(35^{\circ} \mathrm{C}\right)=\frac{3.7441 \mathrm{meq} / \mathrm{kg}-2.0732 \mathrm{meq} / \mathrm{kg}}{0.0286 \mathrm{meq} / \mathrm{kg} / \mathrm{day}} \\
& =58.42 \text { days } \approx 58 \text { days }
\end{aligned}
$$

Overall data on the rate of deterioration and shelf life of galendos stored at various temperatures can be seen in Table 4.

Table 4. Data on the calculation of the rate of decline Quality and Estimated Shelf Life of Galendo's

\begin{tabular}{|c|c|c|}
\hline $\mathbf{T}\left({ }^{\circ} \mathbf{C}\right)$ & Rate of Decline Quality $(\mathbf{k})$ & Shef Life (days) \\
\hline 15 & 0,0207 & 83 \\
\hline 25 & 0,0247 & 67 \\
\hline 35 & 0,0286 & 58 \\
\hline
\end{tabular}

When compared to the data above, it is possible to predict changes in the rate of reaction or the rate of deterioration of the quality of food products stored at different temperatures, using the $\mathrm{Q}_{10}$ model. The $\mathrm{Q}_{10}$ model is also known as the reaction acceleration factor. 
By entering the shelf life of galendo at $15^{\circ} \mathrm{C}, 25^{\circ} \mathrm{C}$, and $35^{\circ} \mathrm{C}$, the $\mathrm{Q}_{10}$ value of galendo's which is packaged in vacuum aluminum foil packaging is as follows:

$\mathrm{Q}_{10}\left(15^{\circ} \mathrm{C}-25^{\circ} \mathrm{C}\right)$ :

ts $\left(15^{\circ} \mathrm{C}\right) /$ ts $\left(25^{\circ} \mathrm{C}\right)=83$ days $/ 67$ days $=1.23$

$\mathrm{Q}_{10}\left(25^{\circ} \mathrm{C}-35^{\circ} \mathrm{C}\right)$ :

ts $\left(25^{\circ} \mathrm{C}\right) /$ ts $\left(35^{\circ} \mathrm{C}\right)=67$ days $/ 58$ days $=1.16$

There is a difference in the value of $\mathrm{Q}_{10}$, that it turns out that the value of $\mathrm{Q}_{10}$ depends on temperature if the activation energy (EA) is considered constant. The relationship between $\mathrm{Q}_{10}$ and EA can be derived as follows:

$\mathrm{Q}_{10}=\mathrm{k}_{(\mathrm{T}+10)} / \mathrm{k}_{\mathrm{o}} \mathrm{e}^{-\mathrm{EA} / \mathrm{RT}}$

$=\mathrm{k}_{\mathrm{o}} \mathrm{e}^{-\mathrm{EA} / \mathrm{R}(\mathrm{T}+10)} / \mathrm{k}_{\mathrm{o}} \mathrm{e}^{-\mathrm{EA} / \mathrm{R}}$

$\ln \mathrm{Q}_{10}=\mathrm{E}_{\mathrm{A}} / \mathrm{R}\{1 / \mathrm{T}-1 /(\mathrm{T}+10)\}=\mathrm{E}_{\mathrm{A}} / \mathrm{R}\{10 / \mathrm{T}(\mathrm{T}+10)\}$

$\log 10=10 /(1,986) . \mathrm{EA}_{\mathrm{A}} / \mathrm{T}(\mathrm{T}+10)$

So that: $\log \mathrm{Q}_{10}=5,0352 \mathrm{EA} / \mathrm{T}(\mathrm{T}+10)$

From the above equation, if $E A$ is constant then the value of $Q_{10}$ is not constant, but will increase as the temperature decreases. Therefore, the use of $\mathrm{Q}_{10}$ obtained from high temperatures will result in a shorter shelf life than what actually happened. The peroxide number is commonly used to express the degree of oxidation of fats and oils. Many methods have been recommended for measuring the peroxide number. The determination of the peroxide number is usually based on measuring the amount of iodine liberated from potassium iodide by oxidation by peroxides in oil or fat at room temperature in acetic acid or chloroform medium (Apriyantono, at al., 1989).

The value of the Peroxide Number detected in the Galendo product which was just produced from the processing plant is $1.5652 \mathrm{meq} / \mathrm{kg}$. The value of this peroxide number is still very far from the peroxide value limit which is correlated with the onset of a rancid odor in lard products of $20 \mathrm{mek} / \mathrm{kg}$, $70 \mathrm{meq} / \mathrm{kg}$ of hydrogenated oil and $100 \mathrm{meq} / \mathrm{kg}$ of cottonseed oil and soybean oil at $100 \mathrm{mek} / \mathrm{kg}$ (Fennema, 1976).

The value of peroxide numbers in galendo, when compared with the requirements for the quality of vegetable oil products, namely coconut oil contained in SNI 01-2902-1992 which requires a maximum value of $5 \mathrm{meq} / \mathrm{kg}$, it can be said that the value of the peroxide number from galendo has met the quality requirements. which have been set.

\section{Number of Microorganisms}

In this second phase of research, observations were also made on the total microbes contained in galendo on the first day of storage and on the last day of storage, at each storage temperature level. The results of the total microbial count are as listed in Table 5. Through their growth, microorganisms can cause various physical and chemical changes of a food ingredient. If these changes are unwanted or unacceptable to consumers, the foodstuff is declared unacceptable or rejected by a consumer, but may still be acceptable to other consumers, so that the definition of food damage by microorganisms becomes very subjective. 
Table 5. The Results of the Total Microbial Analysis Of Galendo Were Stored at $1^{\circ} \mathrm{C}, 2^{\circ} \mathrm{C}$ and $35^{\circ} \mathrm{C}$.

\begin{tabular}{|c|c|c|}
\hline Temperature storage & $\begin{array}{c}\text { Total Microbes Early } \\
\text { (colony/g) }\end{array}$ & $\begin{array}{c}\text { Total Microbes End } \\
\text { (colony/g) }\end{array}$ \\
\hline $15^{\circ} \mathrm{C}$ & 145 & 245 \\
\hline $25^{\circ} \mathrm{C}$ & 145 & 395 \\
\hline $35^{\circ} \mathrm{C}$ & 145 & 590 \\
\hline
\end{tabular}

Food damage by microorganisms can cause food or beverages to be unsuitable for consumption due to quality degradation or because the food has become toxic. The decline in the quality of foodstuffs and other agricultural products includes, among others, decreased nutritional value, deviation in color, changes in taste and smell, the presence of decay, modification of chemical composition, and decreased growth of seeds, health problems, namely the presence of pathogenic microorganisms and chemical compound synthesis toxic (bacterial toxins and mycotoxins) both carcinogenic, chronic and acute health problems.

Based on the results of the analysis of the total number of microorganisms as listed in table 6, it shows that the higher the storage temperature, the greater the number of microbes. The largest number of microbes was found at storage at $35 \mathrm{oC}$ as many as 590 colonies/gram and the smallest at $15^{\circ} \mathrm{C}$, which was 245 colonies/gram.

Temperature is one of the environmental factors that influence microbial growth. Each microbe has a certain optimum temperature and temperature range for its growth. Based on the growth temperature range, microbes are divided into three groups, namely Psychrophiles, namely microbes that have a growth temperature range of $0-20{ }^{\circ} \mathrm{C}$; Mesophiles, namely microbes that have a growth temperature range of 20-45 $\circ \mathrm{C}$; and Thermophiles, namely microbes that have a growth temperature above $45{ }^{\circ} \mathrm{C}$. Most of the microbes that destroy food are mesophyll microbes, that is, they grow either at room temperature or room temperature. Pathogenic bacteria generally have an optimum growth temperature of around 37 ${ }^{\circ} \mathrm{C}$, which is also the human body temperature.

Generally, bacteria, yeast and mold grow best at temperatures between 16 - 37 ${ }^{\circ} \mathrm{C}$. Most of the bacteria in their vegetative form will die at a temperature of $82-94$ ${ }^{\circ} \mathrm{C}$, but many bacterial spores are still resistant to boiling water temperatures of 100 ${ }^{\circ} \mathrm{C}$ for 30 minutes. For sterilization, that is, so that the microbes and their spores die, it is necessary to heat them at a higher temperature, for example $121{ }^{\circ} \mathrm{C}$ for 15 minutes or more, depending on the quantity and quality of the substrate. This is usually done using hot steam, for example in an autiklave or rhetoric.

Microbes have different oxygen requirements for their growth. Based on their need for oxygen, microbes can be divided into four groups as follows:

a. Aerobes, namely microbes that need oxygen for growth

b. Anaerobic, namely microbes that grow without the need for oxygen

c. Facultative anaerobes, namely microbes that can grow with or without oxygen 
d. Microaerophils, namely microbes that require oxygen at a lower concentration than normal oxygen concentration in air.

The total microbial value analyzed serves to assess the safety aspects of stored food. The total number of microbes present in food is calculated to determine the level of freshness and quality of the product during storage. Microorganisms that can cause damage or decay are bacteria, yeast and molds.

The microorganisms that may be in the galendo are mainly molds and bacteria. Mold is a type of microorganism that can grow on materials with low and moderate levels. The optimal temperature for mold growth is around $25-30{ }^{\circ} \mathrm{C}$. Fungi are aerobic microbes that need oxygen for their growth. Mold can take advantage of various types of food sources from simple to complex. Most fungi have the ability to produce hydrolytic enzymes such as amylase, pectinase, proteinase and lipase. The initiation of mold growth is slower than other types of microorganisms. So if on a substrate whose conditions allow for the growth of all three types of microorganisms, then the mold will lose, but when the mold has grown, it will develop very quickly.

\section{CONCLUSION}

Based on the research results, it can be concluded that in the storage treatment of galendos packed with vacuum aluminum foil at several temperature levels $\left(15{ }^{\circ} \mathrm{C}\right.$, $25^{\circ} \mathrm{C}$ and $35^{\circ} \mathrm{C}$ ), it can be calculated that the estimated shelf life of galendos stored at $15{ }^{\circ} \mathrm{C}$ is 83 days, at $25^{\circ} \mathrm{C}$ is 67 days and at a temperature of $35{ }^{\circ} \mathrm{C}$ for 58 days. So the lower the storage temperature of galendos, the longer the shelf life of galendos will be obtained.

There is a difference in the value of $Q_{10}$ in comparing the rate of reaction rate of peroxide formation at galendo, namely in the comparison between the shelf life at $15{ }^{\circ} \mathrm{C}$ and $25{ }^{\circ} \mathrm{C}$, the $\mathrm{Q}_{10}$ value is 1.23 , while in the comparison of the shelf life of galendo's at $25{ }^{\circ} \mathrm{C}$ and $35^{\circ} \mathrm{C}$, the $\mathrm{Q}_{10}$ value is 1.16 . The highest number of microbes was obtained at galendo which was stored at $35{ }^{\circ} \mathrm{C}$, which was 590 colonies/gram, at $25{ }^{\circ} \mathrm{C}$ it was 395 colonies/gram and the smallest was at $15{ }^{\circ} \mathrm{C}$, which was 245 colonies/gram.

\section{REFERENCES}

1. Anonymous. (2002). Mengemas Galendo Ala Silver Queen dan Tango. Jakarta: Harian Republika.

2. Anonymous. (2004). Pembuatan Minyak Kelapa dengan Pemanasan Bertahap. Manado: Balai Pengkajian dan Pengembangan Teknologi Pertanian (BP2TP) Sulawesi Utara.

3. Anonymous. (2007). Data Produksi Galendo. Retrieved from http://www.smkn1cms.sch.id/ciamis/ potensi.html.

4. AOAC. (1995). Official Methods of Analysis Assoc. Washingthon D. C.: Offic. Anal.Chem. 
5. Arpah, M. (2001). Penentuan Kadaluwarsa Produk Pangan. Bogor: Program Pasca Sarjana Institut Pertanian Bogor.

6. Fardiaz, S. (1992). Food Microbiology. Jakarta: Gramedia Pustaka Utama.

7. Faridah, D. N., Yasni, S., Suswantinah, A., \& Aryani, G. W. (2013). Estimated Age Save with the Accelerated Shelf-Testing Method on Instant Bandrek Products and Nutmeg Fruit Syrup (Myristica Fragnans). Jurnal Ilmu Pertanian Indonesia (JIPI), 18(3), 144-153.

8. Ganje, M., Jafari, S. M., Dusti, A., Dehnad, D., Amanjani, M., \& Ghanbari, V. (2016). Modeling quality changes in tomato paste containing microencapsulated olive leaf extract by accelerated shelf life testing. Food Bioprod. Process, 97, 12-19.

9. Gunaratne, T. M., Gunaratne, N. M., \& Navaratne, S. B. (2015). Selection of best packaging method to extend the shelf life of rice crackers. International Journal of Scientific E Engineering Research, 6(2).

10. Gundewadi, G., Rudra, S. G., Sarkar, D. J., \& Singh, D. (2018). Nanoemulsion based alginate organic coating for shelf life extension of okra. Journal and books of Food Packaging and Shelf Life, 18, 1-12.

11. Haryati, H., Estiasih, T., Sriherfyna, F. H., \& Ahmadi, K. (2014). Pendugaan Umur Simpan Menggunakan Metode Accelerated Shelf-life Testing (ASLT) dengan Pendekatan Arrhenius Pada Produk Tape Ketan Hitam Khas Mojokerto Hasil Sterilisasi. Jurnal Pangan dan Agroindustri, 3(1), 156-165.

12. Herawati, H. (2008). Penentuan Umur Simpan Pada Produk Pangan. Jurnal Litbang Pertanian, 27(4), 124-130.

13. Kebede, B. T. et al. (2015). An integrated fingerprinting and kinetic approach to accelerated shelf-life testing of chemical changes in thermally treated carrot puree. Food Chem, 179, 94-102.

14. Koswara, S. (2006). Pendugaan Umur Simpan Produk Bahan Pangan. Retrieved from http://www.ebookpangan.com

15. Koswara, S. (2006). Aplikasi Mutu Sensori Sebagai Kriteria dalam Penentuan Masa Kadaluwarsa. Retrieved from http://www.ebookpangan.com

16. Sewald, M., \& DeVries, J. (2003). Food Product Shelf Life. Medallion Laboratories Analytical Progress.

17. Simbolon, N. P. E., Setiani, B. E., \& Legowo, A. M. (2019). Estimation of Shelf Life Pasta Spice for Dekke Mas Na Niura with the Accelerated Shelf Life Test (ASLT) Method Arrhenius Equation. Journal of Applied FoodTechnology, 6(2).

18. Syarief, R., \& Halid. (1993). Teknologi Penyimpanan Pangan. Jakarta: Arcan.

19. Winarno, F. G. (2002), Kimia Pangan dan Gizi. Jakarta: Gramedia Pustaka Utama.

20. Wiroi. (2007). Industri Kelapa Nasional Masih Bernilai Tambah Rendah. Retrieved from http://agribisnis.deptan.go.id/agromedia. 